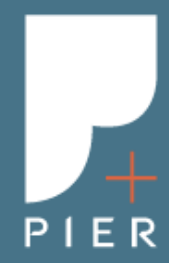

PUEY UNGPHAKORN INSTITUTE FOR ECONOMIC RESEARCH

\title{
On Covid-19: New Implications of Job Task Requirements and Spouse's Occupational Sorting
}

\section{With a supplementary paper}

A Revisit on Covid-19 Sectoral lockdown and Labor Supply: Evidence from Thailand

by

Warn N. Lekfuangfu, Suphanit Piyapromdee, Ponpoje Porapakkarm and Nada Wasi

April 2020

Discussion Paper

No. 133
The opinions expressed in this discussion paper are those of the author(s) and should not be attributed to the Puey Ungphakorn Institute for Economic Research. 


\title{
On Covid-19: New Implications of Job Task Requirements and Spouse's Occupational Sorting
}

\author{
Warn N. Lekfuangfu, Suphanit Piyapromdee, Ponpoje Porapakkarm and Nada Wasi*
}

\begin{abstract}
$\underline{\text { Abstract }}$
The Covid-19 pandemic has disrupted working life in many ways, the negative consequences of which may be distributed unevenly under lockdown regulations. In this paper, we construct a new set of pandemic-related indices from the Occupational Information Network $\left(\mathrm{O}^{*} \mathrm{NET}\right)$ using factor analysis. The indices capture two key dimensions of job task requirements: (i) the extent to which jobs can be adaptable to work from home; and (ii) the degree of infection risk at workplace. The interaction of these two dimensions help identify which groups of workers are more vulnerable to income losses, and which groups of occupations pose more risk to public health. This information is crucial for both designing appropriate supporting programs and finding a strategy to reopen the economy while controlling the spread of the virus. In our application, we map the indices to the labor force survey of a developing country, Thailand, to analyze these new labor market risks. We document differences in job characteristics across income groups, at both individual and household levels. First, low income individuals tend to work in occupations that require less physical interaction (lower risk of infection) but are less adaptable to work from home (higher risk of income/job loss) than high income people. Second, the positive occupational sorting among low-income couples makes them less able to partially insure themselves. Consequently, low-income families tend to face a disproportionately larger risk of income/job loss from lockdown measures. In addition, the different exposure to infection and income risks between income groups can play an important role in shaping up the timing and optimal strategies to unlock the economy.
\end{abstract}

\section{Warn N. Lekfuangfu}

Department of Economics,

Universidad Carlos III de Madrid

nlekfuan@eco.uc3m.es

\section{Ponpoje Porapakkarm}

National Graduate Institute for Policy

Studies (GRIPS)

p-porapakkarm@grips.ac.jp

\section{Suphanit Piyapromdee \\ Department of Economics, University College London \\ s.piyapromdee@ucl.ac.uk.}

\section{Nada Wasi}

Puey Ungphakorn Institute for Economic Research, Bank of Thailand

NadaW@bot.or.th

Key words: Covid-19; Labor Market; Work-from-home; Physical proximity; Occupational sorting

JEL Code: D10, E24, J12, J21

\footnotetext{
* First draft: 24 April 2020. The authors thank Peter Spittal for helpful comments.
} 


\section{Introduction}

Unlike previous economic shocks, Covid-19 has disrupted labor markets around the world along two new dimensions. First, workers in certain jobs are at higher risk of infection and transmission, particularly those working in close physical proximity to other people. Second, workers whose jobs are not adaptable to work from home may have a higher risk of income loss due to drastic measures (e.g. sectoral lockdowns and social distancing) to curb the spread of virus. Identifying the tradeoffs between the risks of economic loss and public health across occupations is essential to understanding the potentially heterogeneous impact across workers of Covid-19 and policies designed to contain it. Some households may be much more exposed to such risks if both spouses sort into similar occupations, and so face common shocks. Socially desired exit strategies require a substantial balance between pandemic containment and economic burdens - both of which may involve rather different sets of stakeholders.

In this paper, we exploit the information on job task requirements of each occupation from the Occupational Information Network $\left(\mathrm{O}^{*} \mathrm{NET}\right)$ to construct a set of new pandemic-related indices using factor analysis. Specifically, these indices measure (i) the degree of job flexibility in terms of work location (due to job reliance on machinery or specific location; and adoption of ICT into task performance), and (ii) the extent to which jobs require the worker to perform tasks in close physical proximity with others. We show that these statistically-constructed indices can represent two important risks posed by the Covid-19 pandemic on workers: the risk of earnings losses when a worker is away from their regular workplace, and the risk of contracting or spreading the virus at the workplace.

Further, the interactions of these indices along the earnings distribution can be informative for designing programs to support different groups of affected workers as well as strategies to reopen the economy. For example, workers who cannot adapt to work from home may require more support than those who can, especially if work location flexibility is negatively correlated with earnings. On reopening the economy, the debate is around how to minimize the economic losses while controlling the spread of the virus. Our analysis suggests that workers in jobs which are not adaptable to work from home, but do not require frequent physical contact with others, should be allowed to return to their workplaces first. On the other hand, those who usually work in close physical proximity to others, but whose jobs are well-suited to work from home, may be the last to return to normalcy.

As an application, we focus our analysis of the impact of the pandemic on a developing economy. With relatively low social safety nets and large shares of workers in the informal sector with weak labor protections, workers in developing countries stand a higher risk of earnings loss in the presence of a global economic and public health crisis such as the Covid-19 pandemic. To investigate such potential impact, our analysis focuses on Thailand. ${ }^{1}$ We map the latest release of Thailand's Labor Force Survey (2019) with the O*NET-derived indices, and evaluate the labor market risks arising from the Covid-19 crisis at both individual and household levels. ${ }^{2}$ In developing countries, risk-

\footnotetext{
${ }^{1}$ Despite the relatively few Covid-19 cases at present, Thailand was one of the countries with the highest number of Covid-19 cases outside China at the onset of the crisis (January 2020), owing to the largest number of daily direct passenger flights from Wuhan. By mid-March of 2020, the Thai government declared a state of emergency - with the implementation of strict sectoral lockdown regulations, and social distancing practice.

2 The structure variable definitions and survey conduct in the Thai Labor Force Survey are analogous to the European Union's Labor Force Survey (EU LFS) and the US's Current Population Survey (CPS). We use the third quarter data because it includes seasonal workers. Workers included in the LFS work in both formal and
} 
sharing within households plays a central role in absorbing shocks (e.g., Chiappori et al. 2014, Samphantharak and Townsend 2018). Therefore, if Covid-19 exposes both primary earners in a household to common shocks, the impact on their livelihoods can be severe. Insights from our analysis on Thailand are highly relevant for other countries with similar labor market structures specifically, a relatively large share of self-employment and low social safety net.

First, we document that there are noticeable differences in occupational indices among individuals from different income groups. Specifically, people with lower earnings tend to face a lower infection risk at the workplace, but a higher risk of income or job losses due to the difficulty in adjusting their working arrangement following a sectoral lockdown. Second, the occupational sorting within married couples reinforces these differences at the household level. Married couples from the lower end of earnings distribution are much more likely to sort into occupations with similar indices, and are concentrated in jobs not adaptable to work from home. In effect, earnings within low-income households are highly correlated, which makes them less able to partially insure themselves, leading to more inequality in risks across households. This suggests that means-tested emergency relief programs would be more suitable than universal support programs in terms of targeting those working in most adversely affected occupations.

This paper is closely related to works studying the labor market consequences of lockdown measures using occupational characteristics. Hicks (2020) recently uses the O*NET data on the degree of physical proximity to assess which occupations are more likely to be affected. Focusing on work flexibility characteristics, Dingle and Neiman (2020) and del Rio-Chanona et al. (2020) manually classify occupations into a binary variable whether they can be performed at home. ${ }^{3}$ Our main contribution is to show that (i) physical proximity, (ii) work-location flexibility and (iii) their interactions are crucial for impact evaluation and policy design in response to the pandemic. Our work is directly complementary to Adams-Prassl et al. (2020) which provides evidence from real-time surveys that workers with limited work arrangement are highly exposed to less favorable job outlooks. Additionally, we complement the literature of household economics by showing that the differences in labor market risks induced by Covid-19 across households can be mitigated at various degrees depending on the occupational sorting pattern between husbands and wives.

The paper proceeds as follows: Section 2 describes how the indices are constructed using the O*NET. Section 3 applies the indices to evaluate labor market risks at individual and household levels in the Thai context. Section 4 discusses policy recommendations and Section 5 concludes.

\section{Methodology}

We select 24 task-based occupational variables from the $\mathrm{O}$ *NET data on 'Work Context' and 'Work Activities' to capture (i) the extent to which a job can be done at home, and (ii) whether a job requires working in close proximity with other people. The latter group of characteristics is particularly important for policy decision-making during the pandemic as the virus can easily be transmitted from person to person. (See the Appendix for the list of the selected O*NET variables.)

informal employment (defined by social security and health insurance status), as well as those in agricultural sector.

${ }^{3}$ Other papers using task characteristics to classify occupations to evaluate structural changes of labor markets include seminal work by Autor and Dorn (2013) and Blinder (2009). 
To reduce the dimensionality of the $\mathrm{O} *$ NET variables, we perform an exploratory factor analysis with rotation method to establish a factor retention criterion. We impose oblique rotation of factor loadings to allow for correlation between the factors (Heckman et al., 2013). We retain three factors with eigenvalues greater than 2, following the criteria outlined by Gorsuch (1988). ${ }^{4}$ Table A1 in the Appendix presents the factor loadings on the predicted factors. A larger factor loading (in absolute terms) reflects higher correlation between the selected $\mathrm{O}$ *NET variable and the factors. The factors are standardized to have mean zero and standard deviation one.

The first factor encapsulates tasks related to repairing, maintaining, or inspecting equipment, structure or materials and operating vehicles or mechanized devices. Thus, we interpret this factor as a measure of both machine and location dependence of jobs. The second factor captures tasks that frequently utilise ICT - for example interacting with computer, analyzing data or processing information. The last factor captures whether the job often requires workers to perform tasks in close physical proximity to other people or to assist or care for others. For conciseness, in the rest of the paper, we will refer to these factors as indices for 'machine-dependent', 'ICT-enabled' and 'physical proximity', respectively.

We compute the three factor indices for over 900 detailed six-digit occupations (based on the US SOC 2010). We present a selected list of occupations with the highest and lowest scores in each factor in the Appendix. Note that the partial correlations of machine-dependent and ICT-enabled; machinedependent and physical proximity; and ICT-enabled and physical proximity among the occupation list in the O*NET database are $-0.40,0.05$, and 0.16 respectively. Small and statistically insignificant correlations of machine-dependent and physical proximity of occupations suggest that a lockdown restriction in response to the pandemic crisis may involve a trade-off along multiple dimensions, e.g. saving jobs versus preventing infection. The effects of the Covid-19 shock on jobs are therefore likely to be quite different from other economic shocks in past recessions.

Table 1 summarizes the average indices of the three factors derived from the O*NET by the broad occupation groups in columns 2, 3 and 5. While machine-dependent and ICT-enabled are separate factors, the ease of shifting work location from 'office' to home are highly depended on both factors in opposing directions. ${ }^{5}$ To ease our analysis, we also report an equally-weighted average of the scores of machine-dependent (reversed) and ICT-enabled factors in column 4, and refer to the additional index as the score of overall work-location flexibility. Broadly speaking, managers and professionals have relatively high degrees of work-location flexibility. Service and sale workers have the highest average indices of physical proximity.

The last three columns compare occupational compositions of workers in Thailand, EU-27 and the U.S. While the occupational shares of EU-27 and the U.S. are similar, the shares of Thailand reflect a common pattern of a middle-income economy - relatively large agricultural and manufacturing sectors with a lower share of workers in the high skill service sector (e.g. managers, professionals, technicians, and associated professionals).

Our analysis draws attention to the interaction between the degree of work-location flexibility and close physical proximity. While a lack of work-location flexibility indicates the risk of income losses

\footnotetext{
${ }^{4}$ Statistical criteria for factor retention include the Scree Test, Onatski's Test and Horn's Test.

${ }^{5}$ For instance, a market research survey interviewer has a low index of machine-dependent, but because interviews were typically done face-to-face before the pandemic, this occupation is associated with a low score of ICT-enabled. Without ICT infrastructure, it is unlikely that these interviewers could easily perform their work from home.
} 
due to the inability to work during a lockdown, the physical proximity factor emphasizes the risk of virus infection and transmission in performing such tasks. In the event of a pandemic, performing such tasks is seriously discouraged; therefore, jobs with a high value of physical proximity index may also be exposed to income losses.

Table 1. Average Score of Factors and Occupational Distribution

\begin{tabular}{|c|c|c|c|c|c|c|c|}
\hline \multirow[b]{2}{*}{$\begin{array}{c}\text { Occupational Groups } \\
(1 \text { Digit })\end{array}$} & \multicolumn{3}{|c|}{ Work Location-Flexibility Indices } & \multirow[b]{2}{*}{$\begin{array}{l}\text { Physical } \\
\text { Proximity }\end{array}$} & \multicolumn{3}{|c|}{ Share of workers, $2019(\%)$} \\
\hline & $\begin{array}{c}\text { i. Machine- } \\
\text { Dependent } \\
(-)\end{array}$ & $\begin{array}{c}\text { ii. ICT- } \\
\text { Enabled } \\
(+)\end{array}$ & $\begin{array}{c}\text { Average } \\
\text { of } \\
-[2] \&[3]\end{array}$ & & US & EU-27 & Thailand \\
\hline [1] & {$[2]$} & {$[3]$} & [4] & {$[5]$} & [6] & [7] & {$[8]$} \\
\hline 1. Managers & -0.22 & 0.87 & 0.67 & 0.56 & 11.07 & 4.23 & 3.66 \\
\hline 2. Professionals & -0.73 & 0.66 & 0.85 & -0.01 & 22.65 & 19.38 & 5.41 \\
\hline $\begin{array}{l}\text { 3. Technicians and } \\
\text { associate professionals }\end{array}$ & 0.09 & 0.35 & 0.16 & 0.33 & 14.28 & 17.81 & 4.32 \\
\hline $\begin{array}{l}\text { 4. Clerical support } \\
\text { workers }\end{array}$ & -0.74 & -0.14 & 0.36 & 0.09 & 9.89 & 10.89 & 4.42 \\
\hline $\begin{array}{l}\text { 5. Service and sales } \\
\text { workers }\end{array}$ & -0.16 & -0.61 & -0.28 & 0.79 & 17.89 & 16.69 & 20.06 \\
\hline $\begin{array}{l}\text { 6. Skilled agricultural, } \\
\text { forestry, fishery workers }\end{array}$ & 0.99 & -0.92 & -1.17 & -0.86 & 0.17 & 0.95 & 31.50 \\
\hline $\begin{array}{l}\text { 7. Craft and related trades } \\
\text { workers }\end{array}$ & 0.73 & -0.98 & -1.05 & -0.41 & 8.38 & 11.53 & 10.59 \\
\hline $\begin{array}{l}\text { 8. Plant and machine } \\
\text { operators, assemblers }\end{array}$ & 1 & -1.23 & -1.36 & -0.59 & 5.76 & 8.54 & 9.40 \\
\hline 9. Elementary occupations & 0.54 & -1.25 & -1.09 & -0.35 & 9.90 & 9.97 & 10.64 \\
\hline
\end{tabular}

Note: The indices are standardized to have mean zero and standard deviation one. Source: EU-27 occupational shares come from EU Statistics, US shares come from Bureau of Labor Statistics, and Thailand shares come from Thai Labor Force Survey.

Figure 1: Occupation Classification
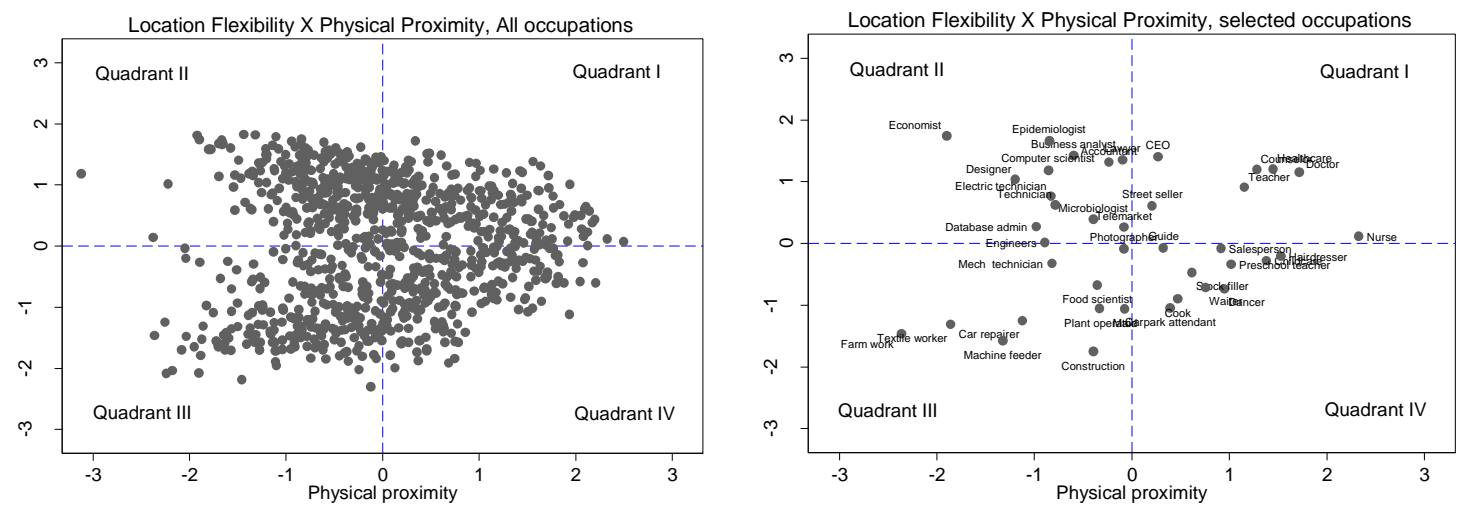

Note: Factors are standardized to have mean zero and standard deviation one. 
Figure 1 depicts the interactions between these two indices. The vertical axis represents the degree of work-location flexibility, and the horizontal axis shows the degree of physical proximity. The left panel illustrates that the 968 occupations from $\mathrm{O}^{*}$ NET are distributed across all the quadrants. The right panel shows a selected list of occupations in each quadrant. Workers with occupations in quadrant IV (bottom-right) are arguably the most vulnerable group with respect to both income losses and getting infected at workplaces because they have relatively low degree of work-location flexibility and high degree of physical proximity. Workers with occupations in quadrant III (bottomleft) are also limited in their work arrangements but have jobs with less physical contact and correspondingly lower infection risk at their workplaces. Those in quadrants I and II (top-right and top-left) have jobs which are more flexible. We discuss the policy implications in more detail in Section 4.

\section{Evaluating the New Labor Market Risks}

Our analysis focuses on measuring supply-side labor market risks associated with various measures to slow down the infection rates. These include closing businesses in some or most sectors and requiring non-essential workers to work from home. We focus our study on potential labor market risks at occupation level using our occupation classification. ${ }^{6}$ Our case study is based on Thailand. Despite the relatively low official number of infections, the country mobilized to slow down the outbreak of Covid-19 by imposing strict sectoral lockdowns and campaigning for social distancing in late March 2020.

In section 3.1, we analyze the potential risks at the individual level. In section 3.2, we extend our analysis to households. Incorporating the role of assortative marriage, this section assesses to what extent occupational sorting of spouses alters the income risk among different types of households. Insights from our analysis on Thailand are highly relevant for other countries with similar labor market structures - specifically, a relatively large share of self-employment and low social safety net. In term of marriage patterns, Thailand has seen increasing assortative marriage over the past decades, a pattern common to many developed and developing countries (see Chiappori, 2017 for a review).

We map the indices to the Thai 2019 Labor Force Survey (LFS), a quarterly nationally representative sample. For each sampling household, detailed information from all members is collected. This includes demographic characteristics, marital status, employment status, work hours, occupations and sectors. While the complete information on occupation is available for all types of workers (wage or salary workers, self-employed and unpaid workers), earnings data were collected only for wage or salary workers. For individual analysis, we restrict the sample to workers aged between 15 and 65 years old. For household analysis, we further use the subsample of married couples.

\subsection{Individual Heterogeneity}

Table 2 reports the average indices across genders, age groups and education levels. On average, occupations held by older and lower educated workers tend to be more machine-dependent, less ICT-enabled, and have a lower degree of close physical proximity. On average, jobs held by Thai

\footnotetext{
${ }^{6}$ Because the actual lockdown sectors differ across countries, we do not explicitly incorporate the sectoral lockdown to analyze the labor market risks. See a companion analysis in Lekfuangfu et al. (2020), where we documented the differences in the lockdown sectors in Thailand and European countries.
} 
men are less flexible but require less physical contact than jobs held by Thai women. This is because a higher proportion of men work as assemblers or machine operators in factories and agricultural activities, while a higher proportion of women are in sales and services.

Table 2. Average Factors by Worker Characteristics

\begin{tabular}{|c|c|c|c|c|c|}
\hline & \multicolumn{3}{|c|}{ Work-Location Flexibility Indices } & \multirow[b]{2}{*}{$\begin{array}{l}\text { Physical } \\
\text { Proximity }\end{array}$} & \multirow[b]{2}{*}{$\begin{array}{r}\text { Total number } \\
\text { of workers } \\
\text { (millions, \%) }\end{array}$} \\
\hline & $\begin{array}{l}\text { i. Machine- } \\
\text { Dependent (-) }\end{array}$ & $\begin{array}{c}\text { ii. ICT- } \\
\text { Enabled } \\
(+) \\
\end{array}$ & $\begin{array}{c}\text { Average } \\
\text { Index }\end{array}$ & & \\
\hline National & 0.41 & -0.61 & -0.62 & -0.25 & 37.3 \\
\hline \multicolumn{6}{|l|}{ Gender } \\
\hline Male & 0.60 & -0.59 & -0.73 & -0.30 & $20.4(55 \%)$ \\
\hline Female & 0.17 & -0.63 & -0.49 & -0.19 & $17.1(45 \%)$ \\
\hline \multicolumn{6}{|l|}{ Age groups } \\
\hline $15-25$ & 0.41 & -0.75 & -0.71 & -0.22 & $4.3(12 \%)$ \\
\hline $26-35$ & 0.21 & -0.51 & -0.43 & -0.09 & $8.3(23 \%)$ \\
\hline $36-45$ & 0.31 & -0.53 & -0.51 & -0.18 & $8.7(24 \%)$ \\
\hline $46-55$ & 0.40 & -0.61 & -0.67 & -0.39 & $8.8(25 \%)$ \\
\hline $56-65$ & 0.62 & -0.72 & -0.82 & -0.46 & $5.5(16 \%)$ \\
\hline \multicolumn{6}{|l|}{ Education Levels } \\
\hline Secondary or lower & 0.53 & -0.73 & -0.77 & -0.28 & $31.6(85 \%)$ \\
\hline College & -0.47 & 0.25 & 0.44 & 0.29 & $6.1(15 \%)$ \\
\hline
\end{tabular}

To understand how the job task requirements are mapped into earnings, Figure 2 plots the indices across earnings deciles. Workers with lower earnings work in occupations that are more machinedependent and less ICT-enabled, making them less flexible to work remotely. Thus, lower earning workers are more exposed to the risk of losing income during the pandemic than higher earning workers. The degree of physical proximity, however, is reversed. Lower paid workers tend to be the laborers (e.g., fixing streets, construction site) and those who work in factories whose work naturally involves less close physical interaction.

Since the Covid-19 shock adversely affected people's health and income, it creates political tensions between people from different groups which can play an important role in shaping policy in response to the crisis. Glover, et al. (2020) emphasize the tension between people outside the labor market ("the old") and those participating in the labor market ("the young"). The old face a higher mortality risk of being infected but little (or no) earnings risk; the opposite is true for the young. Consequently, the old may prefer more drastic measures or delays to opening the economy. Our findings reveal an additional tension among workers in the labor market which has not previously been discussed. While those from a lower earnings bracket face a lower infection risk, they may endure a larger economic loss from having a lockdown imposed on them due to the difficulty in adjusting their work arrangements. Therefore, these workers would prefer an earlier removal of the lockdown. The opposite may be true for the high-income group. 
Figure 2. Work Characteristics by Earnings Decile

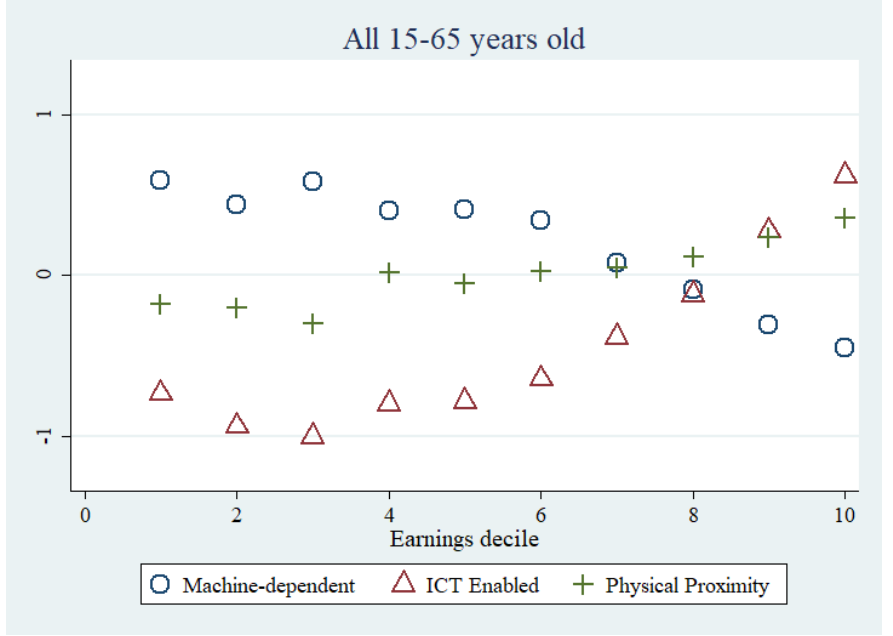

Notes: The figure shows average score in each factor index along the earnings distribution. The horizontal axis is the ranking position of individual wage earners on the earnings distribution of all wage earners observed in the LFS 2019, quarter 3.

\section{Figure 3. Work Characteristics by Gender and Education}
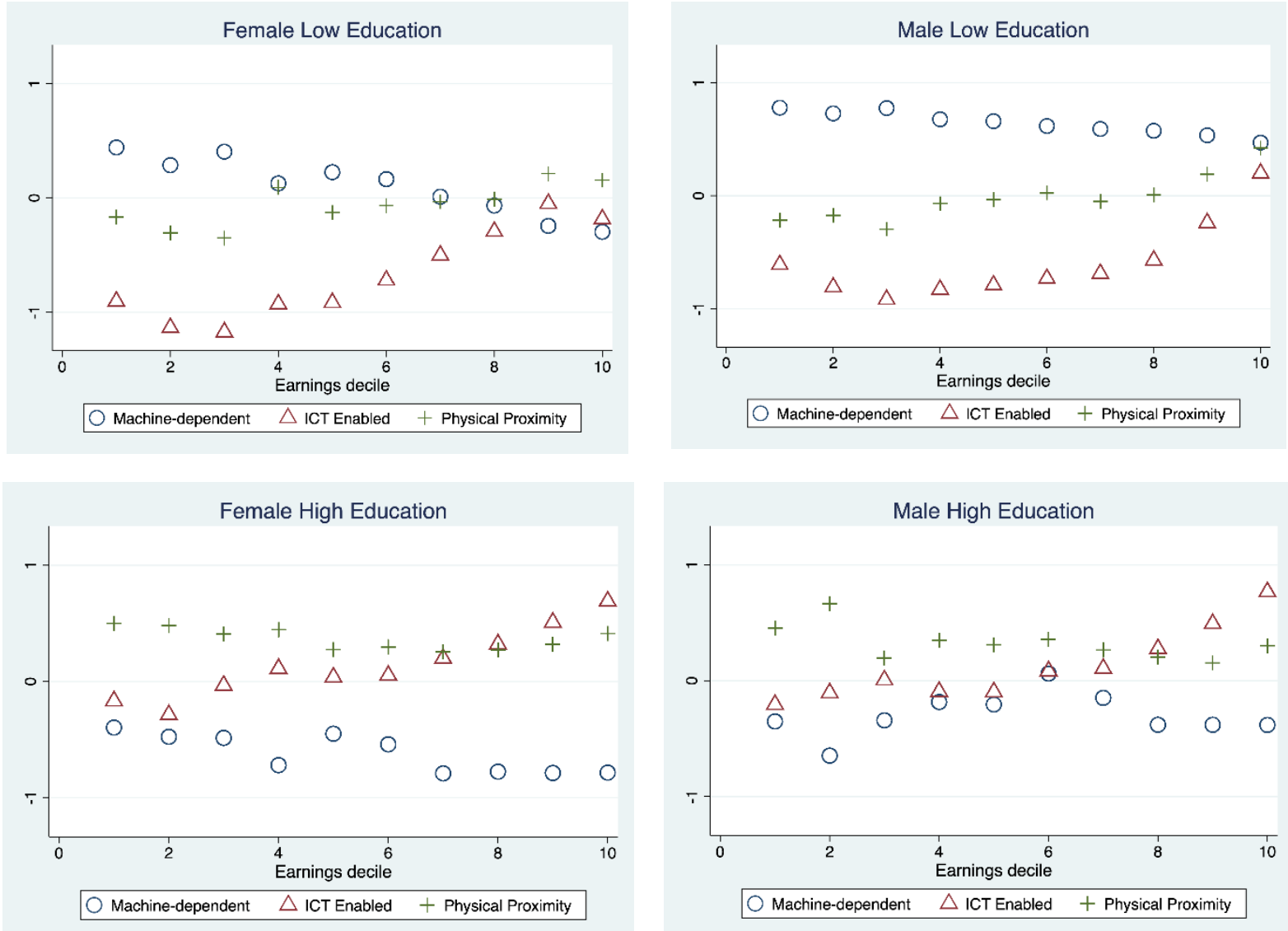

Notes: We use common earnings decile as in Figure 2. 
Figure 3 plots the indices across earnings decile conditional on gender interacted with education level. There are stark differences between occupational characteristics of workers with and without a college degree along the earnings distribution. The average indices shown in Table 2 capture the characteristics of workers with at most secondary education who have a much larger share in the workforce. However, conditional on having a college degree or higher, the differences between occupations of males and females are modest. Nevertheless, the pandemic-induced risk of earnings losses at the household level depends on the composition of the household. That is, households with more dissimilarity of occupations with respect to the flexibility to work from home and physical proximity are in a better position to smooth the negative income shock. On the other hand, households with both primary earners working in low physical proximity and flexible jobs would be best off, while households with both partners having limited work-location flexibility would face much harsher economic implications. ${ }^{7}$

\subsection{Household's Correlated Risks}

The inequity in impact of the pandemic on individuals' earnings discussed in the previous section can be either mitigated or magnified at the household level through occupational sorting within households. We examine this point by focusing our analysis on households in which both spouses work. To shed light on the pattern of occupational sorting, we report the correlation of each index between the husband's and wife's job separately for different types of households.

To account for a large share of Thailand's informal sector (33\% self-employed, 17\% unpaid workers and $47 \%$ paid employees), we classify working married couples in our sample into four types as the following:

- Type A: both work as employees

- Type B: one as employee, another as self-employed

- Type C: both spouses are self-employed

- Type D: both work, and at least one works as unpaid family worker ${ }^{8}$

Table 3 displays the spousal correlations of each pandemic-related index (machine-dependent, ICTenabled, physical proximity). For households of types A and D (76.4\% of total), the correlations between indices of jobs held by married couples of all three factors are highly positive. For households of type $\mathrm{D}$, the spousal correlations are close to one - suggesting that most unpaid workers tend to work in the same or similar jobs as their spouses. Thus, for type D, the occupational impact at the household level would be similar to that at the individual level. For type B (one spouse is selfemployed), the negative correlations of machine-dependent and physical proximity factors indicate that these households may have a higher degree of risk sharing through less assortative occupational choices.

\footnotetext{
${ }^{7}$ Moreover, other structures of households, such as whether there are young children or not, could be vital. Given school and day care closures, mothers are more likely to be affected. Being able to work from home might alleviate the impact (see Alon et al. (2020) for a discussion).

${ }^{8}$ Unpaid family workers are people working without actual pay in an enterprise or farm owned by a family member.
} 
Table 3. Married couple correlations by types of employment

\begin{tabular}{llccc}
\hline Types of households & $\begin{array}{l}\text { Total married } \\
\text { workers in } \\
\text { millions (\%) }\end{array}$ & $\begin{array}{c}\text { Machine- } \\
\text { dependent }\end{array}$ & $\begin{array}{c}\text { ICT } \\
\text { Enabled }\end{array}$ & $\begin{array}{c}\text { Physical } \\
\text { Proximity }\end{array}$ \\
\hline A. Both as employees & $4.1(30)$ & 0.39 & 0.56 & 0.44 \\
B. One employee and one self-employed & $1.9(15.3)$ & -0.05 & 0.11 & -0.03 \\
C. Both as self-employed & $1.1(8.3)$ & 0.19 & 0.08 & 0.15 \\
D. One or both as unpaid workers & $6.2(46.4)$ & 0.9 & 0.92 & 0.97 \\
\hline All households & $13.3(100)$ & 0.51 & 0.61 & 0.66 \\
\hline \multicolumn{2}{c}{ Notes: The correlations are weighted by the sum of individual survey weight of the head and of the spouse. }
\end{tabular}

Whether the positive spousal correlations for the job flexibility or physical proximity factors reflect the scale of labor market risk depends predominantly on the magnitude of these indices. For instance, a household is better insulated from a negative shock from lockdown measures when at least one spouse is in an occupation with a low degree of machine dependent and/or high degree of ICTenabled - which implies a higher probability of being able to work from home. In contrast, the Covid19 crisis could cause larger losses in household's income if both spouses lose their jobs because they cannot work from home. Moreover, the impact can substantially worsen income and consumption inequalities if such positive occupational sorting (into jobs with limited locational flexibility) is more prevalent among poor households.

Figure 4. Type A household: both are employees
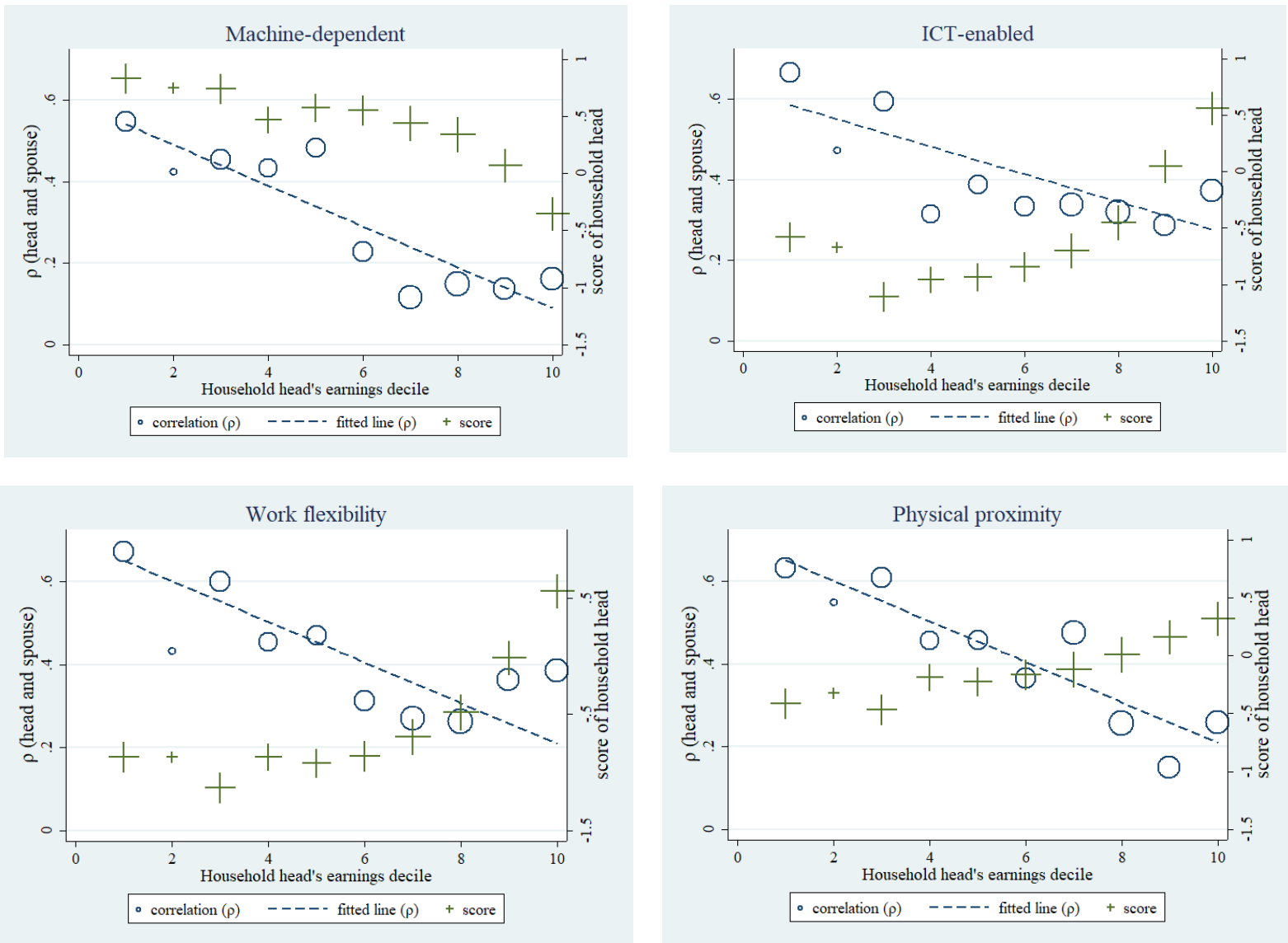
Notes: The figures show spousal correlations in each factor index. The horizontal axis is the ranking position of household heads on the earnings distribution of all wage earning individuals observed in the LFS 2019 (quarter 3). On the horizontal axis, we use the common earnings decile as in Figures 2 and 3.

In what follows, we investigate the pattern of spousal correlations along the earnings distribution. We focus on households of type A for which earnings of both spouses are observed in the data. Figure 4 depicts the spousal correlations of their occupational factor (on the left vertical axis), and the average score of household head for a given factor (the right vertical axis). ${ }^{9}$ It shows that the spousal correlations are strongly positive particularly at the lower-end of the earnings distribution. This suggests that married couples from low-income households work in occupations with common levels of machine-dependent, ICT-enabled and physical proximity. Further, the size of the positive correlation decreases along the earnings decile, in particular for machine-dependent factor. These plots present compelling evidence that labor market risks due to the Covid-19 are heterogeneous across households - and that those at the bottom-end of the earnings distribution are less able to partially insure themselves against the pandemic shock than others.

\section{Policy Implications}

In response to the Covid-19 pandemic, affected countries around the world have introduced various forms of supports to aid their citizens, including emergency cash transfer programs, social assistance, in-kind food and utility and financial obligation waivers. The cash transfer programs appear to be most common with some countries launching a one-off universal transfer whereas others used a means-tested cash transfer, i.e., the cash amount is conditional on household's income or people working in certain occupations (Gentilini et al., 2020).

In Section 3, we show that the degree of potential impacts of Covid-19 on workers depend on the two new dimensions of their job characteristics (the degrees of work-location flexibility and close physical proximity), and these impacts can be intensified by occupational sorting in marriage. Our findings can be used to guide efficient supporting schemes for different targeted groups of workers, and strategies for reopening the economy. At the time of writing, some countries announced that they have been able to slow down the virus outbreak; thus, the recent debate has shifted towards how to open up the economy without jeopardizing the public health systems.

Table 4 demonstrates examples of occupations in the four quadrants deriving from the crossdimensionality between work-location flexibility and physical proximity (as seen in Figure 1). Workers with occupations in quadrant IV (bottom-right) are the most vulnerable group. Due to the high degree of close physical proximity, these jobs have been the first to be restricted, and potentially will be the last to return to normalcy. Unlike workers in quadrants I and II (top-right and top-left), workers in quadrant III (bottom-left) could 'produce' only if they are allowed to return to their workplaces. In fact, those in quadrant II (top-left) may experience relatively mild impacts from the lockdown measures since their jobs are more flexible and do not require frequent physical contact with others.

\footnotetext{
${ }^{9}$ We define household head as the highest earner of the couple. The horizontal axis in Figure 4 represents earnings decile, calculated from all wage workers aged 15-65 years old.
} 
Table 4: Selected occupations in four impact groups

\begin{tabular}{ccc}
\hline Wock $\begin{array}{c}\text { Wocation } \\
\text { Flexibility }\end{array}$ & \multicolumn{2}{c}{ Physical Proximity } \\
\cline { 2 - 3 } & Low & High \\
\hline \multirow{2}{*}{ High } & Quadrant II: & Quadrant I: \\
& Sociologist & Medium impact \\
& Programmer & Human resources manager \\
& Website developer & Fitness manager \\
& Economist & Business strategy manager \\
& Financial advisor & Information coordinator \\
& Legal councillor & Head hunter \\
& Quadrant III: & Secondary school teacher \\
\hline Medium impact & Quadrant IV: \\
& Garment factory worker & Severe impact \\
& Metal worker & Cleaner \\
& Planter, Grower & Restaurant server \\
& Construction worker & Travel organiser \\
& Machine controller & preschool teacher \\
& Production worker & Tour guide \\
& Painter and polisher & Dentist \\
& Gow & Veterinarian \\
\hline
\end{tabular}

Notes: The impact level is derived based on the interactions of work location flexibility and physical proximity.

The composition of workers across the four quantiles is not equally distributed on the earnings distribution. As can be seen in the left panel of Figure 5, there is a substantially larger fraction of workers with occupations in quadrant IV (red) - the severely impacted group - at the lower-end of the earnings distribution. In contrast, workers at the top quintile have the largest share of jobs considered to be mildly affected by the pandemic crisis (based on our occupational classifications) in the short run. This means that without adequate government intervention to support income or employment for the poor, the adverse impact of Covid-19 could worsen income inequality.

The findings suggest that mitigation interventions should be targeted based on job characteristics when possible. ${ }^{10}$ For example, ICT-related support would assist those in quadrant I (top-right) to maintain their work activities. In contrast, the measure would be less effective for those in quadrant III (bottom-left) since their jobs are required to be performed at specific locations. In effect, potential schemes providing substitutions for income losses would be more suited for workers holding jobs in quadrants III and IV. Given that the Covid-19 pandemic is likely to disproportionately affect the low earners, the introduction of means-tested relief programs targeting those working in most adversely affected occupations, rather than a universal program, would be socially desirable.

\footnotetext{
${ }^{10}$ In some sectors such as finance, businesses can continue without all workers being able to work from home since core and non-core activities are divisible e.g. face-to-face customer relation activities can be put on hold while main banking activities can run remotely. However, in some other sectors such as hotels and restaurants, this kind of division is unlikely to be possible. Although their managers and sales may be able to work from home, most service staff work in close physical proximity to others.
} 
Figure 5. Fraction of the derived impact levels by earnings distribution

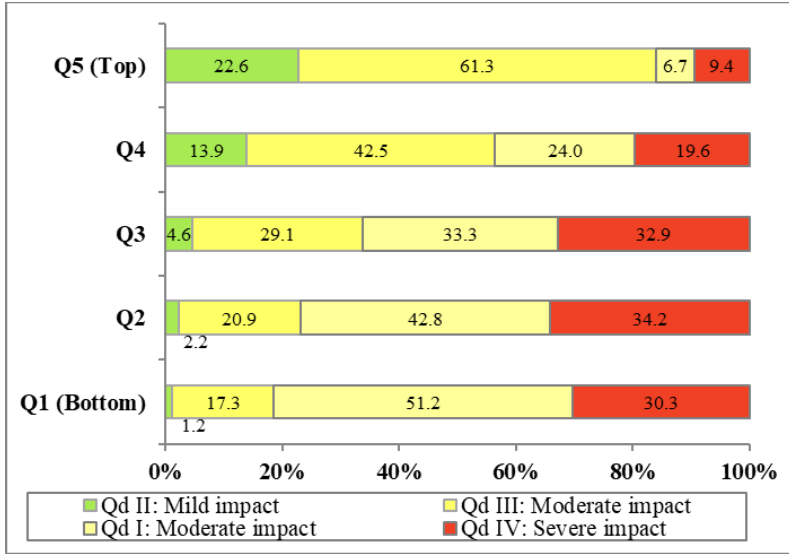

Individuals

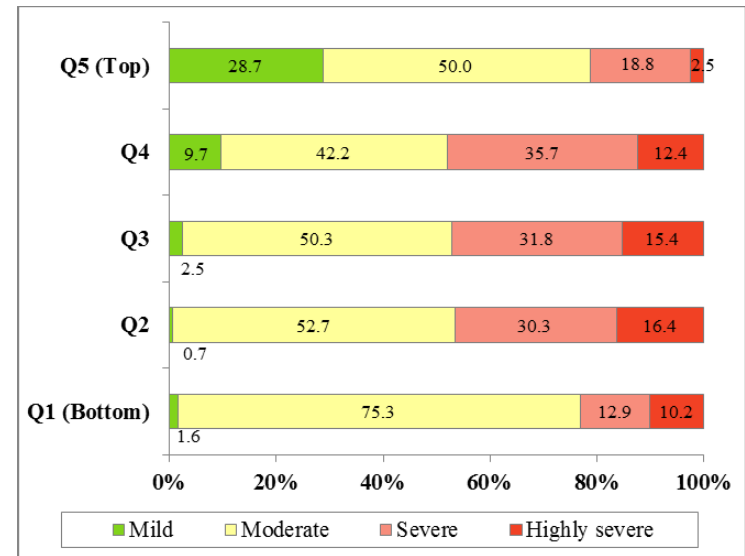

Married couples

Notes: The left panel shows the proportion of wage earning individuals by the derived impact level (based on the interactions of work location flexibility and physical proximity) for each earnings quintile. The right panel shows the proportion of married couples in wage earning employment by the derived impact level. 'Mild' is for households with both spouses' jobs in quadrant II; 'moderate' when no spouse' jobs in quadrant IV; 'severe' when one spouse's job in quadrant IV; 'highly severe' when both spouses' jobs in quadrant IV. For both panels, the ranking position is based on the earnings distribution of all wage earning individuals observed in the LFS 2019 (quarter 3).

The above argument is reinforced when taking into account the high degree of occupational sorting among married couples at the bottom-end of the earnings distribution (as discussed in Section 3.2). The right panel in Figure 5 shows the fractions of at-work married couples (household-level) according to the derived severity of the pandemic impact on their jobs. In this case, we define impact as 'mild' (green) for households with both spouses in jobs of quadrant II, 'moderate' (yellow) for households without any spouse's job in quadrant IV; 'severe' (orange) for households with one spouse's job in quadrant IV, and 'highly severe' (red) when both spouses' jobs are in quadrant IV.

The top earnings quintile has noticeably the largest fraction of households classified as mildly impacted (green) and the smallest fraction of households classified as 'highly severe' (red). In contrast, married couples who both work in occupations in quadrant IV are of the highest fraction in the middle quintile groups. A large fraction of the bottom quintile couples are classified as moderate impact because many low wage occupations are based in factories which require less physical interaction. Overall, our findings suggest that suitable relief schemes, for instance income transfers, should be means-tested with criteria based on specific occupational characteristics as well as joint household earnings.

As for reopening the economy, other things being equal (for instance, health, age of household members, the infection rate and healthcare capacity in the area), our results and the application of the occupation indices, discussed earlier, indicate that the highest priority to relax lockdown regulations should be given to workers in occupations in quadrant III (bottom-left). Without returning to their workplace, these workers face a high risk of income losses. Additionally, allowing them to return to work may involve minimal infection transmission risk since their works require limited physical contact with others. 


\section{Conclusion}

The Covid-19 pandemic has posed new types of risks on workers around the world. Given the rapid transmission from person to person of the virus, drastic measures such as lockdowns and social distancing have been imposed to control the spread of infection. Despite differences in the scope of sectoral lockdowns across countries, these measures undoubtably come with sizable costs to the economy.

The direct effect of a lockdown can have different impacts on workers with different job characteristics. To understand such heterogenous impacts, we use a factor analysis to construct a set of occupational indices that are general but relevant to study the impacts of the Covid-19 pandemic. These indices feature two key dimensions of job task requirements: the degrees of work-location flexibility and working in close physical proximity to others. The former captures the risk of the worker's income loss, and the latter captures the infection risk posed to the worker and the public. We show that occupations in the O*NET are broadly distributed over these two dimensions.

Using the data from Thailand, we document that low earners tend to work in occupations that are less adaptable to work from home, but their jobs usually do not require frequent physical interaction with others. Furthermore, we show evidence that spouses in low-income households sort into similar jobs that are less amenable to work from home. This occupational sorting makes low-income households less able to partially insure themselves, amplifying inequality in income risk during the lockdown period. Our findings offer evidence supporting the use of means-testing in assistance programs to ease the burden of those immediately affected by the drastic measures. Our indices can also be useful when designing a policy to reopen the economy with the goal of minimizing the income and job losses while controlling the spread of the virus.

Finally, our study takes the first step to analyzing the impact of the pandemic from the labor supply side. Fruitful avenues for future research include (i) incorporating the labor demand side (incorporating, for example, the decline in consumption and supply-chain effects); (ii) allowing for substitutions - cases in which workers switch to jobs requiring similar skills or, over the longer term, adjust their skills; and (iii) using our constructed indices as supplementary classifications of jobs in order to further track the labor market adjustments as a result of the pandemic in the long run.

\section{References}

Adams-Prassl, A, Boneva, T., Golin, M., and Rauh, C. (2020) Inequality in the Impact of the Coronavirus Shock: Evidence from Real Time Surveys, mimeo

Alon, T. M., Doepke, M., Olmstead-Rumsey, J., and Tertilt, M. (2020). The Impact of COVID-19 on Gender Equality (No. w26947). National Bureau of Economic Research.

Autor, D.H. and Dorn, D. (2013). 'The growth of low skill service jobs and the polarization of the US labor market', American Economic Review, 5(100), 1553-97.

Blinder, A.S. (2009). How many US jobs might be offshorable? World Economics, 2(10), 41-78.

Chiappori, P. A. (2017). Matching with transfers: The economics of love and marriage. Princeton University Press.

Chiappori, P. A., Samphantharak, K., Schulhofer-Wohl, S., and Townsend, R. M. (2014).

Heterogeneity and risk sharing in village economies. Quantitative economics, 5(1), 1-27. 
del Rio-Chanona, R. M., Mealy, P., Pichler, A., Lafond, F., \& Farmer, D. (2020). Supply and demand shocks in the COVID-19 pandemic: An industry and occupation perspective. CEPR Covid Economics: Vetted and Real-Time Papers, 6.

Dingel, J. and Neiman, B. (2020), How many jobs can be done at home? CEPR Covid Economics: Vetted and Real-Time Papers, 1.

Gentilini, U., Almenfi, M., Orton, I, and Dale, P. (2020). Social Protection and Jobs Responses to COVID-19: A Real-Time Review of Country Measures. Live Document. World Bank, Washington, $D C$

Glover, A., Heathcote, J., Krueger, and D., Rios, V. (2020), Health vs Wealth: On the distributional effects of controlling a pandemic, CEPR Covid Economics: Vetted and Real-Time Papers, 6, 22 64.

Gorsuch, R. L. (1988). Exploratory factor analysis. In Handbook of multivariate experimental psychology (pp. 231-258). Springer, Boston, MA.

Heckman, J., Pinto, R., \& Savelyev, P. (2013). Understanding the mechanisms through which an influential early childhood program boosted adult outcomes. American Economic Review, 103(6), 2052-86.

Hicks, M. J., Faulk, D., \& Devaraj, S. (2020). Occupational Exposure to Social Distancing: A Preliminary Analysis using O* NET Data.

Lekfuangfu, N.W., Piyapromdee, S., Porapakkarm, P., Wasi, N. (2020). 'Sectoral Lockdowns: Labor Supply Analysis in Thailand', aBRIDGEd article, Puey Ungphakorn Institute for Economic Research.

Samphantharak, K., \& Townsend, R. M. (2018). Risk and return in village economies. American Economic Journal: Microeconomics, 10(1), 1-40. 


\section{Appendix: Construction of the indices from O*NET variables}

We select a list of Work Activities (14 items) and Work Context (14) from the O*NET work characteristics as described in Table A1.

\section{Table A1. Selected $O *$ NET variables}

\begin{tabular}{|c|c|}
\hline $\begin{array}{l}\text { Work Activities variables: we take the Importance Score of } \\
\text { each activity (measured on the } 0-100 \text { scale). }\end{array}$ & $\begin{array}{l}\text { Work Context variables: we use the original scale } \\
(0,25,75,100)^{11}\end{array}$ \\
\hline $\begin{array}{ll}\text { - } & \text { Assisting and Caring for Others } \\
\text { - } & \text { Performing for or Working Directly with the Public } \\
\text { - } & \text { Repairing and Maintaining Electronic Equipment } \\
\text { - } & \text { Repairing and Maintaining Mechanical Equipment } \\
\text { - } & \text { Operating Vehicles, Mechanized Devices, or } \\
\text { - } & \text { Equipment } \\
\text { - } & \text { Interacting With Computers } \\
\text { - } & \text { Handling and Moving Objects } \\
\text { - } & \text { Documenting or Recording Information } \\
\text { - } & \text { Controlling Machines and Processes } \\
\text { - } & \text { Thinking Creatively } \\
\text { - } & \text { Processing Information } \\
\text { - } & \text { Analyzing Data or Information } \\
\text { - } & \text { Inspecting Equipment, Structures, or Material }\end{array}$ & $\begin{array}{ll}\text { - } & \text { Structured versus Unstructured Work } \\
\text { - } & \text { Pace Determined by Speed of Equipment } \\
\text { - } & \text { Freedom to Make Decisions } \\
\text { - } & \text { Spend Time Walking and Running } \\
\text { - } & \text { Physical Proximity } \\
\text { - } & \text { Outdoors, Under Cover } \\
\text { - } & \text { Outdoors, Exposed to Weather } \\
\text { - } & \text { Telephone } \\
\text { - } & \text { Work With Work Group or Team } \\
\text { - } & \text { Public Speaking } \\
\text { - } & \text { Responsible for Others' Health and Safety } \\
\text { - } & \text { Electronic Mail } \\
\text { - } & \text { Face-to-Face Discussions } \\
\text { - } & \text { Contact With Others }\end{array}$ \\
\hline
\end{tabular}

Table A2: Selected list of occupations with highest and lowest scores (3 factors)

\begin{tabular}{lll}
\hline \multicolumn{1}{c}{ Machine-Dependent } & \multicolumn{1}{c}{ ICT-Enabled } & \multicolumn{1}{c}{ Physical Proximity } \\
\hline Panel A: Top scores & Chemical engineers & Nurses* \\
Metal workers & Chief executives & Personal care workers \\
Fire-fighters* & Community leaders & Child care services managers \\
Refrigeration mechanics & Mining engineers & Midwifes* \\
Well drillers & Supply distribution managers & Traditional medicine professionals \\
Freight handlers & Police officers* & Ambulance workers* \\
Miners and quarries & Inspectors and detectives & Customs and border inspectors* \\
Ships' engineers & Mechanical engineers & Paramedical practitioners* \\
Boiler operators & Biologists & Veterinarians* \\
Electronics mechanics & Services managers & Police officers* \\
Forestry plant operators & & \\
\hline Panel B: Bottom scores & Weaving machine operators & Visual artists \\
Legal professionals & Laundry machine operators & Livestock farm laborers* \\
Economists & Shoemaking operators & Subsistence crop farmers* \\
Mathematicians & Subsistence crop farmers & Weaving machine operators \\
Credit and loans officers & Livestock farm labourers & Shoemaking machine operators \\
Higher education instructors & Tobacco products makers & Economists \\
Health professionals* & Pelt dressers & Garment makers \\
Arts teachers & Sewing machine operators & Sewing machine operators \\
Language teachers & Horticultural labourers & Subsistence fishers* \\
Human resource managers & Fibre machine operators & Hunters and trappers \\
Survey interviewers & Notes: *denote occupations regarded as 'essential' in the Covid-19 pandemic. \\
\hline
\end{tabular}

\footnotetext{
${ }^{11}$ The scale indicates either the frequency of task, or the importance of the task required in each occupation.
} 
A Revisit on Covid-19 Sectoral lockdown PUEY UNGPHAKORN INSTITUTE FOR ECONOMIC RESEARCH

and Labor Supply: Evidence from

Thailand

by

Warn N. Lekfuangfu, Suphanit Piyapromdee, Ponpoje Porapakkarm and Nada Wasi

May 2020 


\title{
A Revisit on Covid-19 Sectoral Lockdown and Labor Supply: Evidence from Thailand
}

Warn N. Lekfuangfu, Suphanit Piyapromdee, Ponpoje Porapakkarm and Nada Wasi

May 8, 2020

\begin{abstract}
Countries around the world have imposed various degrees of lockdowns during the Covid-19 pandemic, and some have begun to ease their restrictions. This report provides an analysis of the lockdown impacts across industries under three scenarios for Thailand: (i) full lockdown (the European-style), (ii) partial lockdown (based on Bangkok measures effective on March 22, 2020), and (iii) eased lockdown (effective on May 3, 2020). The pandemic-related indices created from job characteristics and distribution of occupations in each industry from the Thai Labor Force Survey (2019 Q3) are used to assess heterogeneity of the lockdown impact across sectors. We find that the ease of lockdown effective on 3 May 2020 could release 0.87 to 2.37 million workers back to work if their jobs still exist. However, since most of the released activities are classified as posing high public health risk, ensuring that these activities follow social distancing guidelines is extremely crucial. The 'impact' discussed in this report, however, only captures the direct and short-run effect of Covid-19 on workers through temporarily business closure. A more thorough analysis to measure the overall effects of Covid-19 should take into account other factors, such as changes in consumption, supply-chain reconfiguration, and demand for labor, when more data becomes available.
\end{abstract}

Warn N. Lekfuangfu

Department of Economics, Universidad Carlos III de Madrid

nlekfuan@eco.uc3m.es

\section{Ponpoje Porapakkarm}

National Graduate Institute for Policy

Studies (GRIPS)

p-porapakkarm@grips.ac.jp

\section{Suphanit Piyapromdee}

Department of Economics, University College London

s.piyapromdee@ucl.ac.uk.

\section{Nada Wasi}

Puey Ungphakorn Institute for Economic Research, Bank of Thailand

NadaW@bot.or.th 
The severity of the lockdown impact is measured based on a set of pandemic-related indices created from the Occupational Information Network (O*NET) introduced in Lekfuangfu et al. (2020). ${ }^{13}$ The indices capture two key dimensions of job task requirements: (i) the extent to which jobs can be adaptable to work from home (due to job reliance on machinery or specific location; and adoption of ICT into task performance); and (ii) the extent to which jobs require the worker to perform tasks in close physical proximity with others. While the former measures the risk of earnings losses when a worker is away from their regular work location, the latter measures the risk of contracting or spreading the virus at the workplace.

Figure 1 shows the extreme case if all industries had been in a lockdown (the Europeanstyle full lockdown) on the one-digit International Standard Industrial Classification (ISIC). Figure 2 depicts the actual lockdown scenario in Thailand based on the announcement by the Bangkok metropolitan authority that has effectively closed down twenty-five groups of activities in late March, 2020.

Figures 1 and 2 use the interaction between these two indices to classify workers into four groups. Workers with occupations in relatively high degree of physical proximity and low degree of work-location flexibility are arguably the most vulnerable group with respect to both income losses and getting infected at workplaces (high prox, low flex, red). Workers whose jobs do not require frequent physical contacts with others, but are less adaptable to work from home are classified as facing moderate impacts (low prox, low flex, orange). Workers whose jobs require frequent physical contacts with others, but can easily work from home (high prox, high flex, yellow) are also considered receiving moderate impactspresumably they face lower risks than the former group since they can reduce physical interactions with others by working from home. Finally, those whose jobs are both flexible and less physical contacts with others are classified as mildly affected (low prox, high flex, green). In both figures, the numbers in parentheses show employment shares across sectors.

In Figure 1, we show the impact if all industries had been in a lockdown. The lockdown employment shares, in this case, correspond to the sectoral employment shares. For Thailand, sectors with large employment shares are agriculture, forestry and fishing (34\%), manufacturing (16\%), trade (16\%) and accommodation and service activities (8\%). Among these sectors, workers in accommodation and service activities would face the highest impact. Further, agriculture, forestry and fishing; manufacturing; mining and quarrying; and utility

${ }^{13}$ Lekfuangfu, W., Piyapromdee, S., Porapakkarm, P., Wasi, N. 'On Covid-19: New Implications of Job Task Requirements and Spouse's Occupational Sorting', Covid Economics: Vetted and Real-Time Papers, Issue 12, May 1,2020. 
services sectors have large fractions of workers whose jobs are not adaptable to work from home. However, their jobs do not require frequently contact with others. Trade comprises workers who receive both severe and moderate impacts. The information and communication and the professional, scientific, and technical activity sectors have the highest shares of workers facing mild impacts, but these two sectors only account for $1.5 \%$ of all workers.

Figure 2 plots the differential degree of the lockdown impact across the top 20 industries (five-digit ISIC), which accounts for $80 \%$ of employees in the lockdown sector, effective in late March. For restaurant activities, beverage serving activities, childcare, hairdressing-salons, over 90 percent of their workers faced severe risks in terms of both income losses and virus infection. Notably, restaurant activities and hairdressing-salons are among the selected activities allowed to reopen (or partially open) in early May 2020.

To understand how the ease of lockdown on 3 May 2020 has altered the distributional consequences, Table 1 presents the number of workers in each five-digit ISIC sector that could potentially be affected by different lockdown measures. ${ }^{14}$ The column 'Lockdown 03/22/2020' is based on the Bangkok lockdown measures (effective on March 22, 2020) for activities required to be temporarily closed. ' $\mathrm{F}$ ' and ' $\mathrm{P}$ ' refer to full lockdown, and partial lockdown, respectively. Most retailed stores are coded as ' $\mathrm{P}$ ' as non-essential stores in shopping malls or community malls have been ordered to close while those operating outside malls may remain open. Restaurant activities may open for takeaway food. The column 'Unlock 05/03/2020' refers to the Bangkok measures which allow selected activities to reopen under certain conditions on May 3, 2020. ' $U$ ' and 'PU' refer to unlock, and partially unlock, respectively. Based on the initial unlock announcement, markets, restaurants outside shopping malls may open. While zoos remain close, public parks can open. Outdoor individual sports activities are permitted. The last column ' $s$ ' denotes industry with a small cell size (the number of unweighted observations less than 50), indicating that the associated indices can be imprecise, and thus should be interpreted with caution.

According to our estimate, the March lockdown in Thailand has directly affected 6 million workers. However, we find that the negative consequences are distributed unevenly under the lockdown regulations. The differential impacts of lockdown are measured by the 'machine-dependent', 'ICT-enabled' and 'physical proximity' indices. ${ }^{15}$ As expected, most

\footnotetext{
14 The five-digit codes are based on the ISIC-2009, or equivalent the Thailand SIC-2009.

15 The 'machine-dependent' index capture both machine and location dependence of jobs. For examples, task related to repairing, maintaining, or inspecting equipment, structure or materials and operating vehicles or mechanized devices. The 'ICT-enabled' index factor captures tasks that frequently utilise ICT - for example interacting with computer, analyzing data or processing information. The 'physical proximity' captures whether
} 
activities and businesses which have been regulated by the lockdown measures are associated with a high degree of physical proximity factor. However, for the ICT-enabled factor, there exists differences across lockdown activities within the same broadly defined sector. For instance, among retails in lockdown, retail businesses selling non-perishable goods, for example books, music equipment have a positive ICT-enabled index. In contrast, retails selling perishable goods such as food-and-beverage and stall-and-market retails have a negative ICT-enabled index. For educational activities, most of education activities show a positive ICT-enabled index, except for the pre-school education, special education for handicapped students, and dance-music-spa treatment instruction.

Overall, the unlock measures could release 0.87 to 2.37 million workers back to work if their jobs still exist. While the ease of lockdown may lower economic costs, it is vital to recognize that most of these unlocked activities are classified as posing high public health risk. Strict monitoring of how these activities follow social distancing guidelines is extremely crucial if the government wants to balance between economic gains and public health risk.

the job often requires workers to perform tasks in close physical proximity to other people or to assist or care for others. 
Figure 1. Heterogeneous impacts across sectors in a full lockdown scenario

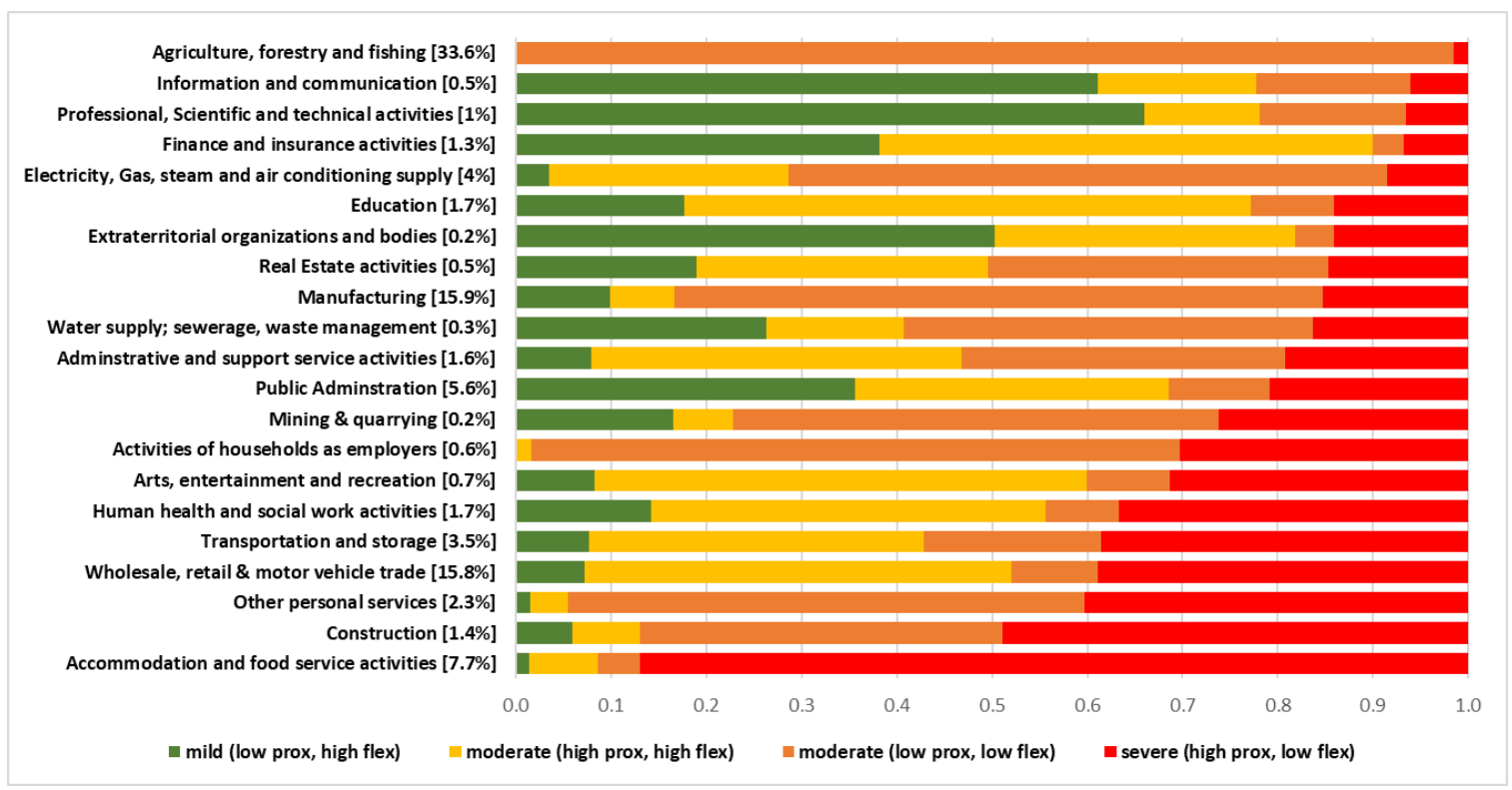

Source: Authors' calculation based on the Thai labor force survey (2019 Q3).

\section{Figure 2. Heterogeneous impacts across sectors in an actual partial lockdown scenario}

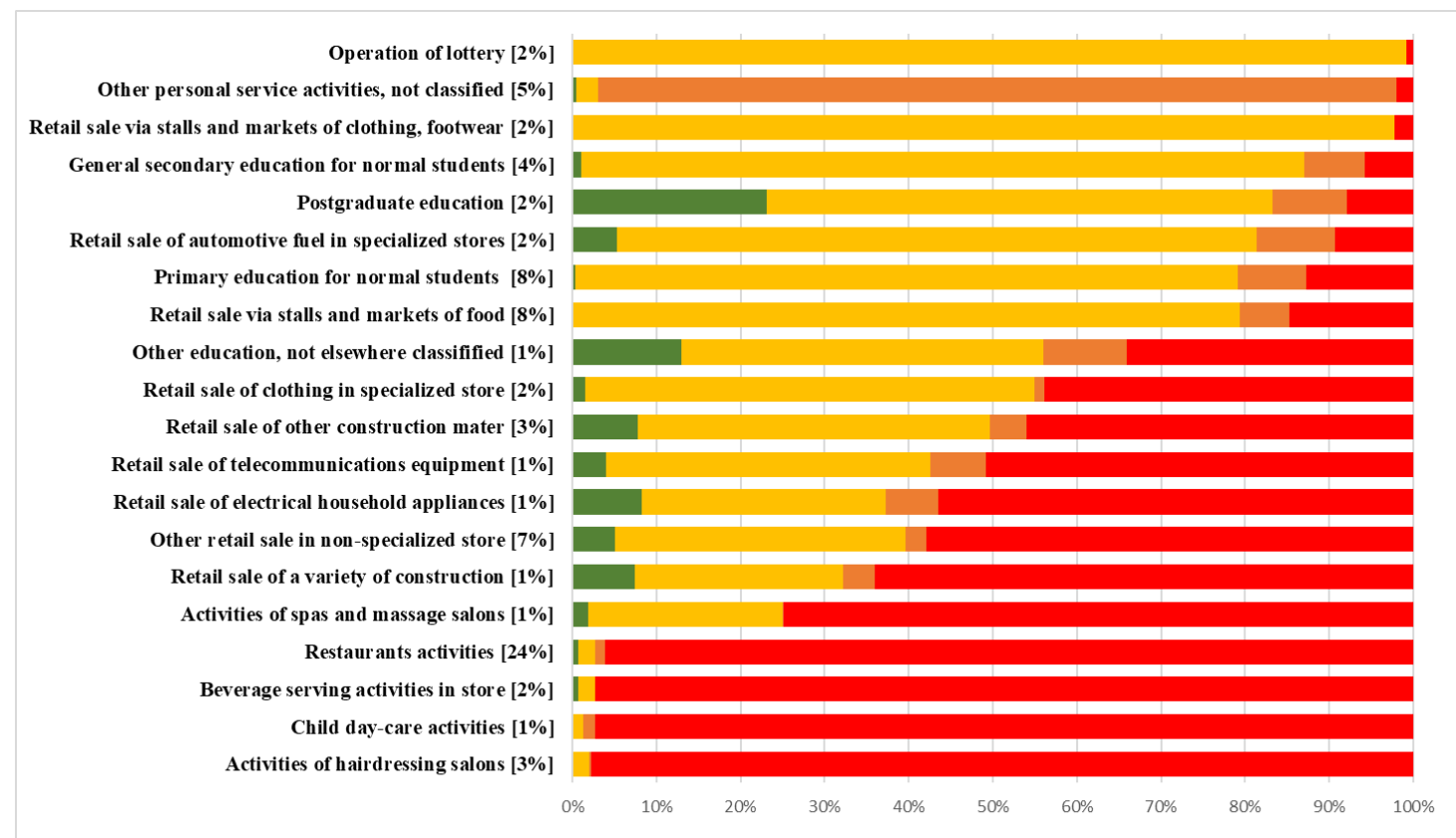

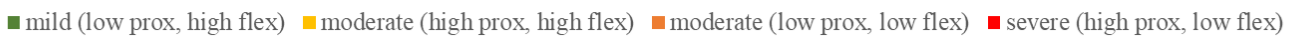

Source: Authors' calculation based on the Thai labor force survey (2019 Q3). 
Table 1. Lockdown impact by detailed sectors and their pandemic-related indices of job characteristics

\begin{tabular}{|c|c|c|c|c|c|c|c|c|c|}
\hline \multirow[b]{2}{*}{ ISIC } & \multirow[b]{2}{*}{ Industry } & \multirow[b]{2}{*}{ Weighted freq. } & \multirow[b]{2}{*}{$\begin{array}{c}\text { Share } \\
(\%)\end{array}$} & \multirow[b]{2}{*}{$\begin{array}{l}\text { Lockdown } \\
\text { 03/22/2020 }\end{array}$} & \multirow[b]{2}{*}{$\begin{array}{c}\text { Unlocked } \\
\text { 05/03/2020 }\end{array}$} & \multicolumn{3}{|c|}{ Average indices } & \multirow[b]{2}{*}{$\begin{array}{l}\text { small no. } \\
\text { of obs. }\end{array}$} \\
\hline & & & & & & $\begin{array}{c}\text { machine } \\
\text { dependent }\end{array}$ & $\begin{array}{c}\text { ICT } \\
\text { enabled }\end{array}$ & $\begin{array}{c}\text { physical } \\
\text { proximity }\end{array}$ & \\
\hline 47190 & Other retail sale in non-specialized stores & 449,158 & 7.39 & $\mathrm{P}$ & & -0.20 & -0.04 & 0.72 & \\
\hline 47211 & Retail sale of meat and meat products in specialized stores & 13,811 & 0.23 & $\mathrm{P}$ & & -0.65 & -0.48 & -0.04 & $\mathrm{~s}$ \\
\hline 47212 & Retail sale of fish and fish products in specialized stores & 7,933 & 0.13 & $\mathrm{P}$ & & -1.16 & -0.34 & 0.29 & $\mathrm{~s}$ \\
\hline 47213 & Retail sale of fruit and vetgetables in specialized stores & 40,678 & 0.67 & $\mathrm{P}$ & & -0.68 & -0.14 & 0.56 & \\
\hline 47214 & Retail sale of rice in specialized stores & 19,447 & 0.32 & $\mathrm{P}$ & & 0.03 & 0.47 & 0.83 & \\
\hline 47215 & Retail sale of bakery products in specialized stores & 21,697 & 0.36 & $\mathrm{P}$ & & -0.50 & -0.64 & 0.51 & $\mathrm{~s}$ \\
\hline 47219 & Retail sale of other food products in specialized stores & 30,419 & 0.5 & $\mathrm{P}$ & & -0.43 & -0.25 & 0.71 & \\
\hline 47221 & Retail sale of alcohol beverages in specialized stores & 3,897 & 0.06 & $\mathrm{P}$ & & -0.07 & -0.24 & 0.67 & $\mathrm{~s}$ \\
\hline 47222 & Retail sale of non-alcohol beverages in specialized stores & 12,790 & 0.21 & $\mathrm{P}$ & & -0.09 & -0.79 & 0.81 & \\
\hline 47300 & Retail sale of automotive fuel in specialized stores & 106,027 & 1.75 & $\mathrm{P}$ & & 0.25 & 0.26 & 0.74 & \\
\hline 47411 & Retail sale of computers and peripheral units in specialized stores & 21,119 & 0.35 & $\mathrm{P}$ & & -0.12 & -0.13 & 0.44 & $\mathrm{~s}$ \\
\hline 47412 & Retail sale of video game consoles and software in specialized stores & 434 & 0.01 & $\mathrm{P}$ & & -0.30 & -0.43 & 0.92 & $\mathrm{~s}$ \\
\hline 47413 & Retail sale of telecommunications equipment in specialized stores & 69,141 & 1.14 & $\mathrm{P}$ & & -0.13 & 0.12 & 0.68 & \\
\hline 47420 & Retail sale of audio and video equipment in specialized stores & 11,281 & 0.19 & $\mathrm{P}$ & & 0.34 & 0.23 & 0.20 & $\mathrm{~s}$ \\
\hline 47511 & Retail sale of fabrics in specialized stores & 4,115 & 0.07 & $\mathrm{P}$ & & -0.16 & 0.49 & 0.72 & $\mathrm{~s}$ \\
\hline 47512 & Retail sale of household articles of textiles in specialized stores & 7,538 & 0.12 & $\mathrm{P}$ & & -0.20 & -0.03 & 0.86 & $\mathrm{~s}$ \\
\hline 47513 & Retail sale of haberdashery in specialized stores & 2,588 & 0.04 & $\mathrm{P}$ & & -0.48 & 0.12 & 0.53 & $\mathrm{~s}$ \\
\hline 47521 & Retail sale of hardware in specialized stores & 3,198 & 0.05 & $\mathrm{P}$ & & -0.34 & -0.63 & 0.81 & $\mathrm{~s}$ \\
\hline 47522 & Retail sale of paints, varnishes and lacquers in specialized stores & 4,064 & 0.07 & $\mathrm{P}$ & & -0.83 & 0.04 & 0.32 & $\mathrm{~s}$ \\
\hline 47523 & Retail sale of plumbing, heating and sanitary equipment and supplies in specialized stores & 6,307 & 0.1 & $\mathrm{P}$ & & -0.34 & -0.21 & 0.52 & $\mathrm{~s}$ \\
\hline 47524 & Retail sale of other construction materials in specialized stores & 152,632 & 2.51 & $\mathrm{P}$ & & -0.03 & 0.06 & 0.73 & \\
\hline 47525 & Retail sale of a variety of construction materials including do-it-yourself material and equipment & 65,038 & 1.07 & $\mathrm{P}$ & & -0.14 & -0.10 & 0.72 & \\
\hline 47530 & Retail sale of carpets, rugs, wall and floor coverings in specialized stores & 741 & 0.01 & $\mathrm{P}$ & & -0.13 & 0.02 & 0.88 & $\mathrm{~s}$ \\
\hline 47591 & Retail sale of household furniture in specialized stores & 48,633 & 0.8 & $\mathrm{P}$ & & 0.03 & -0.02 & 0.74 & \\
\hline 47592 & Retail sale of chinaware, glassware and kitchenware in specialized stores & 7,301 & 0.12 & $\mathrm{P}$ & & -0.06 & 0.33 & 0.73 & s \\
\hline 47593 & Retail sale of lighting equipment in specialized stores & 2,222 & 0.04 & $\mathrm{P}$ & & 0.07 & 0.22 & 0.74 & $\mathrm{~s}$ \\
\hline 47594 & Retail sale of musical instruments and related equipment in specialized stores & 3,161 & 0.05 & $\mathrm{P}$ & & -0.04 & 0.34 & 0.82 & $\mathrm{~s}$ \\
\hline 47595 & Retail sale of electrical household appliances in specialized stores & 74,427 & 1.23 & $\mathrm{P}$ & & -0.03 & 0.13 & 0.64 & \\
\hline 47599 & Retail sale of other household articles, not elsewhere classified in specialized stores & 15,276 & 0.25 & $\mathrm{P}$ & & -0.18 & 0.26 & 0.47 & \\
\hline 47611 & Retail sale of books, newspapers, periodicals and magazines in specialized stores & 8,661 & 0.14 & $\mathrm{P}$ & & -0.21 & -0.03 & 0.87 & $\mathrm{~s}$ \\
\hline 47612 & Retail sale of stationary and office supplies in specialized stores & 14,152 & 0.23 & $\mathrm{P}$ & & -0.08 & 0.24 & 0.78 & \\
\hline 47620 & Retail sale of music and video recordings in specialized stores & 153 & 0 & $\mathrm{P}$ & & -0.30 & -0.43 & 0.92 & $\mathrm{~s}$ \\
\hline 47630 & Retail sale of sporting equipment in specialized stores & 21,883 & 0.36 & $\mathrm{P}$ & & -0.05 & 0.27 & 0.83 & \\
\hline 47640 & Retail sale of games and toys in specialized stores & 13,059 & 0.21 & $\mathrm{P}$ & & -0.26 & 0.09 & 0.72 & $\mathrm{~s}$ \\
\hline 47691 & Retail sale of Thai handicrafts and souvenirs in specialized stores & 6,744 & 0.11 & $\mathrm{P}$ & & 0.11 & 0.38 & 0.81 & $\mathrm{~s}$ \\
\hline 47699 & Retail sale of other cultural and recreation goods, not elsewhere classified in specialized sto.. & 21,179 & 0.35 & $\mathrm{P}$ & & -0.09 & 0.05 & 0.65 & \\
\hline 47711 & Retail sale of clothing in specialized stores & 120,477 & 1.98 & $\mathrm{P}$ & & -0.21 & 0.16 & 0.74 & \\
\hline 47712 & Retail sale of footwear in specialized stores & 21,753 & 0.36 & $\mathrm{P}$ & & -0.13 & 0.24 & 0.82 & \\
\hline 47713 & Retail sale of leather articles in specialized stores & 10,869 & 0.18 & $\mathrm{P}$ & & 0.02 & 0.44 & 0.85 & $\mathrm{~s}$ \\
\hline 47722 & Retail sale of perfumeries in specialized stores & 314 & 0.01 & $\mathrm{P}$ & & -1.42 & -0.42 & 0.21 & $\mathrm{~s}$ \\
\hline 47723 & Retail sale of cosmetics and toilet preparations in specialized stores & 25,610 & 0.42 & $\mathrm{P}$ & & -0.37 & -0.11 & 0.71 & \\
\hline 47731 & Retail sale of watches, eyeglasses and photographic equipment in specialized stores & 21,666 & 0.36 & $\mathrm{P}$ & & -0.19 & 0.29 & 0.76 & \\
\hline
\end{tabular}




\begin{tabular}{|c|c|c|c|c|c|c|c|c|c|}
\hline \multirow[b]{2}{*}{ ISIC } & \multirow[b]{2}{*}{ Industry } & \multirow[b]{2}{*}{ Weighted freq. } & \multirow[b]{2}{*}{$\begin{array}{c}\text { Share } \\
(\%)\end{array}$} & \multirow[b]{2}{*}{$\begin{array}{l}\text { Lockdown } \\
\text { 03/22/2020 }\end{array}$} & \multirow[b]{2}{*}{$\begin{array}{c}\text { Unlocked } \\
\text { 05/03/2020 }\end{array}$} & \multicolumn{3}{|c|}{ Average indices } & \multirow[b]{2}{*}{$\begin{array}{c}\text { small no } \\
\text { of obs. }\end{array}$} \\
\hline & & & & & & $\begin{array}{c}\text { machine } \\
\text { dependent }\end{array}$ & $\begin{array}{c}\text { ICT } \\
\text { enabled }\end{array}$ & $\begin{array}{c}\text { physical } \\
\text { proximity }\end{array}$ & \\
\hline 47732 & Retail sale of jewellery in specialized stores & 57,303 & 0.94 & $\mathrm{P}$ & & -0.12 & 0.13 & 0.64 & \\
\hline 47733 & Retail sale of flowers, plants and related equipment in specialized stores & 58,108 & 0.96 & $\mathrm{P}$ & & 0.13 & 0.12 & 0.67 & \\
\hline 47734 & Retail sale of pet animals and related equipment in specialized stores & 22,236 & 0.37 & $\mathrm{P}$ & & -0.23 & 0.05 & 0.74 & \\
\hline 47735 & Retail sale of household fuel oil, bottled gas, wood and other fuel in specialized stores & 14,333 & 0.24 & $\mathrm{P}$ & & 0.32 & 0.42 & 0.87 & $\mathrm{~s}$ \\
\hline 47739 & Other retail sale of new goods, not elsewhere classified in specialized stores & 6,952 & 0.11 & $\mathrm{P}$ & & 0.03 & -0.25 & 0.42 & $\mathrm{~s}$ \\
\hline 47741 & Retail sale of antiques & 2,592 & 0.04 & $\mathrm{P}$ & & -0.38 & 0.47 & 0.59 & $\mathrm{~s}$ \\
\hline 47742 & Retail sale of second hand clothing, footwear and leather articles & 3,732 & 0.06 & $\mathrm{P}$ & & -0.88 & -0.37 & 0.29 & $\mathrm{~s}$ \\
\hline 47743 & Retail sale of second hand computer and telecommunication equipment & 1,087 & 0.02 & $\mathrm{P}$ & & -0.28 & -0.59 & 0.80 & $\mathrm{~s}$ \\
\hline 47744 & Retail sale of second hand electric household appliances and consumer electronics & 183 & 0 & $\mathrm{P}$ & & -0.13 & 0.03 & 0.88 & $\mathrm{~s}$ \\
\hline 47745 & Retail sale of second hand books, newspapers, periodicals and magazines & 166 & 0 & $\mathrm{P}$ & & 0.25 & 1.03 & 0.80 & $\mathrm{~s}$ \\
\hline 47749 & Retail sale of other second-hand goods & 1,221 & 0.02 & $\mathrm{P}$ & & 1.10 & 0.66 & 0.76 & $\mathrm{~s}$ \\
\hline 47811 & Retail sale via stalls and markets of food & 458,109 & 7.54 & $\mathrm{P}$ & $\mathrm{U}$ & -1.07 & -0.59 & 0.22 & \\
\hline 47812 & Retail sale via stalls and markets of beverages & 11,003 & 0.18 & $\mathrm{P}$ & $\mathrm{U}$ & -0.12 & -1.51 & 0.74 & $\mathrm{~s}$ \\
\hline 47813 & Retail sale via stalls and markets of tobacco products & 327 & 0.01 & $\mathrm{P}$ & $\mathrm{U}$ & -1.42 & -0.42 & 0.21 & $\mathrm{~s}$ \\
\hline 47821 & Retail sale via stalls and markets of textiles & 6,561 & 0.11 & $\mathrm{P}$ & $\mathrm{U}$ & -1.35 & -0.42 & 0.25 & $\mathrm{~s}$ \\
\hline 47822 & Retail sale via stalls and markets of clothing, footwear and leather articles & 114,634 & 1.89 & $\mathrm{P}$ & $\mathrm{U}$ & -1.38 & -0.41 & 0.23 & \\
\hline 47891 & Retail sale via stalls and markets of computer and telecommunication equipment & 4,905 & 0.08 & $\mathrm{P}$ & $\mathrm{U}$ & -1.01 & -0.30 & 0.02 & $\mathrm{~s}$ \\
\hline 47892 & Retail sale via stalls and markets of electric household appliances and consumer electronics & 1,303 & 0.02 & $\mathrm{P}$ & $\mathrm{U}$ & -0.98 & -0.42 & 0.49 & $\mathrm{~s}$ \\
\hline 47893 & Retail sale via stalls and markets of books, newspapers, periodicals and magazines & 134 & 0 & $\mathrm{P}$ & $\mathrm{U}$ & -1.42 & -0.42 & 0.21 & $\mathrm{~s}$ \\
\hline 47895 & Retail sale via stalls and markets of pharmaceutical and medical goods, perfumeries and toilet .. & 5,630 & 0.09 & $\mathrm{P}$ & $\mathrm{U}$ & -1.38 & -0.33 & 0.14 & $\mathrm{~s}$ \\
\hline 47896 & Retail sale via stalls and markets of watches, eyeglasses and jewellery & 11,857 & 0.2 & $\mathrm{P}$ & $\mathrm{U}$ & -1.18 & -0.10 & 0.28 & $\mathrm{~s}$ \\
\hline 47897 & Retail sale via stalls and markets of flowers, plants, pet animals and pet food & 13,783 & 0.23 & $\mathrm{P}$ & $\mathrm{U}$ & -1.18 & -0.33 & 0.33 & $\mathrm{~s}$ \\
\hline 47899 & Retail sale via stalls and markets of other goods, not elsewhere classified & 28,992 & 0.48 & $\mathrm{P}$ & $\mathrm{U}$ & -1.28 & -0.41 & 0.10 & \\
\hline 56101 & Restaurants activities & $1,432,028$ & 23.57 & $\mathrm{P}$ & PU & 0.16 & -0.92 & 1.05 & \\
\hline 56210 & Event catering & 30,686 & 0.51 & $\mathrm{~F}$ & & 0.12 & -0.75 & 0.94 & \\
\hline 56292 & Operation of canteen & 4,681 & 0.08 & $\mathrm{~F}$ & & 0.31 & -0.72 & 1.16 & $\mathrm{~s}$ \\
\hline 56301 & Beverage serving activities in store, of mostly alcoholic beverages & 42,863 & 0.71 & $\mathrm{~F}$ & & -0.26 & -1.16 & 0.81 & \\
\hline 56302 & Beverage serving activities in store, of mostly non-alcoholic beverages & 141,086 & 2.32 & $\mathrm{~F}$ & & -0.22 & -1.24 & 0.72 & \\
\hline 59140 & Motion picture projection activities & 1,834 & 0.03 & $\mathrm{~F}$ & & -0.19 & -0.40 & 0.42 & s \\
\hline 82301 & Organization of conventions & 298 & 0 & $\mathrm{~F}$ & & 0.67 & 0.10 & 0.36 & $\mathrm{~s}$ \\
\hline 82302 & Organization of trade shows & 15,835 & 0.26 & $\mathrm{~F}$ & & -0.25 & 0.41 & 0.65 & $\mathrm{~s}$ \\
\hline 85101 & Primary education for normal students within the school system & 507,343 & 8.35 & $\mathrm{~F}$ & & -0.74 & -0.06 & 1.03 & \\
\hline 85102 & Primary special education for handicapped students within the school system & 5,929 & 0.1 & $\mathrm{~F}$ & & -0.67 & 0.22 & 1.02 & $\mathrm{~s}$ \\
\hline 85103 & Primary education outside the school system & 762 & 0.01 & F & & & & & $\mathrm{s}$ \\
\hline 85211 & General secondary education for normal students within the school system & 270,570 & 4.45 & $\mathrm{~F}$ & & -0.69 & 0.26 & 0.64 & \\
\hline 85212 & General secondary special education for handicapped students within the school system & 1,302 & 0.02 & $\mathrm{~F}$ & & -0.18 & -0.20 & 0.78 & $\mathrm{~s}$ \\
\hline 85213 & General secondary education outside the school system & 1,500 & 0.02 & $\mathrm{~F}$ & & -0.79 & 0.41 & 0.71 & $\mathrm{~s}$ \\
\hline 85220 & Technical and vocational secondary education & 28,223 & 0.46 & F & & 0.20 & 0.06 & 0.38 & \\
\hline 85301 & Post-secondary non-tertiary education & 11,608 & 0.19 & $\mathrm{~F}$ & & -0.15 & 0.04 & 0.21 & \\
\hline 85302 & Bachelor's degree education & 15,268 & 0.25 & $\mathrm{~F}$ & & -0.56 & 0.08 & 0.14 & $\mathrm{~s}$ \\
\hline 85303 & Postgraduate education & 129,064 & 2.12 & $\mathrm{~F}$ & & -0.79 & 0.37 & 0.02 & \\
\hline 85410 & Sports and recreation education & 7,524 & 0.12 & $\mathrm{~F}$ & & -0.27 & -0.36 & 0.53 & $\mathrm{~s}$ \\
\hline
\end{tabular}




\begin{tabular}{|c|c|c|c|c|c|c|c|c|c|}
\hline \multirow[b]{2}{*}{ ISIC } & \multirow[b]{2}{*}{ Industry } & \multirow[b]{2}{*}{ Weighted freq. } & \multirow[b]{2}{*}{$\begin{array}{l}\text { Share } \\
(\%)\end{array}$} & \multirow[b]{2}{*}{$\begin{array}{l}\text { Lockdown } \\
\text { 03/22/2020 }\end{array}$} & \multirow[b]{2}{*}{$\begin{array}{c}\text { Unlocked } \\
\text { 05/03/2020 }\end{array}$} & \multicolumn{3}{|c|}{ Average indices } & \multirow{2}{*}{$\begin{array}{l}\text { small no } \\
\text { of obs. }\end{array}$} \\
\hline & & & & & & $\begin{array}{c}\text { machine } \\
\text { dependent }\end{array}$ & $\begin{array}{c}\text { ICT } \\
\text { enabled }\end{array}$ & $\begin{array}{c}\text { physical } \\
\text { proximity }\end{array}$ & \\
\hline 85421 & Activities of dance instruction & 661 & 0.01 & $\mathrm{~F}$ & & -1.60 & -0.02 & 0.32 & $\mathrm{~s}$ \\
\hline 85422 & Activities of music instruction & 8,155 & 0.13 & $\mathrm{~F}$ & & -0.76 & -0.12 & 0.45 & $\mathrm{~s}$ \\
\hline 85423 & Activities of art instruction & 1,337 & 0.02 & $\mathrm{~F}$ & & -1.67 & 0.02 & 0.23 & $\mathrm{~s}$ \\
\hline 85429 & Other cultural education & 1,094 & 0.02 & $\mathrm{~F}$ & & -1.67 & 0.02 & 0.23 & $\mathrm{~s}$ \\
\hline 85491 & Activities of language instruction & 9,461 & 0.16 & $\mathrm{~F}$ & & -0.92 & 0.20 & 0.45 & $\mathrm{~s}$ \\
\hline 85493 & Activities of academic tutoring & 13,036 & 0.21 & $\mathrm{~F}$ & & -1.19 & -0.36 & 0.54 & $\mathrm{~s}$ \\
\hline 85494 & Activities of dress making and beauty instruction & 594 & 0.01 & $\mathrm{~F}$ & & & & & $\mathrm{~s}$ \\
\hline 85495 & Activities of spa treatment instruction & 2,592 & 0.04 & $\mathrm{~F}$ & & 0.29 & -2.00 & -1.65 & $\mathrm{~s}$ \\
\hline 85497 & Activities of automobile driving schools & 2,943 & 0.05 & $\mathrm{~F}$ & & -0.61 & -0.26 & 0.20 & $\mathrm{~s}$ \\
\hline 85499 & Other education, not elsewhere classified & 70,097 & 1.15 & $\mathrm{~F}$ & & -0.12 & 0.03 & 0.90 & \\
\hline 85500 & Educational support activities & 1,059 & 0.02 & $\mathrm{~F}$ & & & & & $\mathrm{~s}$ \\
\hline 85601 & Pre-primary education for normal students & 54,075 & 0.89 & $\mathrm{~F}$ & & -0.89 & -1.22 & 0.95 & \\
\hline 85602 & Pre-primary special education for handicapped students & 1,413 & 0.02 & $\mathrm{~F}$ & & -1.00 & -0.66 & 0.94 & $\mathrm{~s}$ \\
\hline 88901 & Child day-care activities & 64,001 & 1.05 & $\mathrm{~F}$ & & -0.73 & -1.23 & 0.89 & \\
\hline 90001 & Creative and arts activities & 7,153 & 0.12 & $\mathrm{~F}$ & & -0.71 & 0.14 & -1.32 & $\mathrm{~s}$ \\
\hline 90002 & Entertainment activities & 45,875 & 0.76 & $\mathrm{~F}$ & & -0.58 & -0.67 & 0.48 & \\
\hline 91011 & Libraries activities & 1,859 & 0.03 & $\mathrm{~F}$ & & -1.00 & 0.34 & 0.18 & $\mathrm{~s}$ \\
\hline 91012 & Archives activities & 564 & 0.01 & $\mathrm{~F}$ & & -0.27 & -0.64 & -1.03 & $\mathrm{~s}$ \\
\hline 91021 & Museums activities & 2,341 & 0.04 & $\mathrm{~F}$ & & 0.18 & -1.01 & -0.02 & $\mathrm{~s}$ \\
\hline 91022 & Operation of historical sites and buildings & 402 & 0.01 & $\mathrm{~F}$ & & 0.35 & -0.85 & -0.02 & $\mathrm{~s}$ \\
\hline 91031 & Botanical and zoological gardens & 6,915 & 0.11 & $\mathrm{~F}$ & $\mathrm{PU}$ & -0.34 & -0.51 & -0.07 & $\mathrm{~s}$ \\
\hline 91032 & Nature reserves activities & 14,480 & 0.24 & $\mathrm{P}$ & & 0.33 & -0.23 & -0.11 & \\
\hline 92001 & Operation of lottery & 93,038 & 1.53 & $\mathrm{P}$ & & -1.29 & -0.32 & 0.26 & \\
\hline 92009 & Other gambling and betting activities & 6,028 & 0.1 & $\mathrm{~F}$ & & -0.62 & -0.31 & 0.59 & $\mathrm{~s}$ \\
\hline 93111 & Operation of sports facilities & 47,703 & 0.79 & $\mathrm{~F}$ & $\mathrm{PU}$ & 0.03 & -0.45 & 0.42 & \\
\hline 93112 & Operation of fitness centers & 6,932 & 0.11 & $\mathrm{~F}$ & & -0.35 & -0.69 & 0.97 & $\mathrm{~s}$ \\
\hline 93120 & Activities of sports clubs & 3,662 & 0.06 & $\mathrm{~F}$ & $\mathrm{PU}$ & 0.04 & 0.20 & 0.32 & $\mathrm{~s}$ \\
\hline 93191 & Activities of producers or promoters of sports events & 74 & 0 & $\mathrm{~F}$ & & -0.19 & 0.20 & 1.05 & $\mathrm{~s}$ \\
\hline 93192 & Activities of sport associations & 1,301 & 0.02 & $\mathrm{~F}$ & $\mathrm{PU}$ & 0.49 & -0.11 & 0.41 & $\mathrm{~s}$ \\
\hline 93199 & Other sports activities, not elsewhere classified & 2,007 & 0.03 & $\mathrm{~F}$ & PU & -0.57 & 0.11 & -0.06 & $\mathrm{~s}$ \\
\hline 93210 & Activities of amusement parks and theme parks & 5,346 & 0.09 & $\mathrm{~F}$ & & 1.03 & -1.04 & -0.06 & $\mathrm{~s}$ \\
\hline 93291 & Activities of recreation parks and beaches & 1,667 & 0.03 & $\mathrm{~F}$ & & -0.94 & -0.11 & 0.88 & $\mathrm{~s}$ \\
\hline 93292 & Activities of amusement and recreation shows & 3,993 & 0.07 & $\mathrm{~F}$ & & -0.46 & -0.72 & 0.85 & $\mathrm{~s}$ \\
\hline 93293 & Operation of games shops and coin-operated games activities & 5,301 & 0.09 & $\mathrm{~F}$ & & -0.07 & 0.47 & 0.28 & $\mathrm{~s}$ \\
\hline 93299 & Other amusement and recreation activities, not elsewhere classified & 5,539 & 0.09 & $\mathrm{~F}$ & & 0.44 & 0.34 & 0.63 & $\mathrm{~s}$ \\
\hline 96101 & Activities of spas and massage salons & 61,731 & 1.02 & $\mathrm{~F}$ & & -0.80 & -0.99 & 0.98 & \\
\hline 96103 & Activities of hairdressing salons & 212,164 & 3.49 & $\mathrm{~F}$ & $\mathrm{U}$ & -0.54 & -1.50 & 0.98 & \\
\hline 96104 & Activities of beauty, manicure and pedicure salons & 28,575 & 0.47 & $\mathrm{~F}$ & & -0.79 & -1.31 & 0.95 & \\
\hline 96302 & Pet care activities & 3,124 & 0.05 & $\mathrm{~F}$ & $\mathrm{U}$ & -0.15 & -0.16 & 1.38 & $\mathrm{~s}$ \\
\hline 96303 & Concession operation of coin-operated personal service machines & 1,026 & 0.02 & $\mathrm{~F}$ & & -0.03 & -0.13 & 0.63 & $\mathrm{~s}$ \\
\hline 96304 & Astrological and spiritualists' activities & 5,048 & 0.08 & $\mathrm{~F}$ & & -0.15 & 0.44 & 1.93 & $\mathrm{~s}$ \\
\hline 96305 & Turkish baths, sauna and steam baths activities & 2,782 & 0.05 & $\mathrm{~F}$ & & 0.37 & -0.92 & 0.20 & $\mathrm{~s}$ \\
\hline 96309 & Other personal service activities, not elsewhere classified & 303,200 & 4.99 & $\mathrm{P}$ & & 1.38 & 0.26 & -0.22 & \\
\hline & Total & $6,075,496$ & 100 & & & & & & \\
\hline
\end{tabular}

